\title{
Analisis Kebutuhan Guru Dan Siswa terhadap Pengajaran Bahasa Rejang sebagai Muatan Lokal di Sekolah Dasar
}

\author{
Maria Botifar ${ }^{a}$, Endry Boeriswati ${ }^{\mathrm{b}}$, Ilza Mayuni ${ }^{\mathrm{c}}$ \\ ${ }^{\text {a }}$ Universitas Negeri Jakarta \\ ${ }^{\mathrm{b}}$ Universitas Negeri Jakarta \\ ${ }^{\mathrm{c}}$ Universitas Negeri Jakarta \\ Pos-el:maria.botifar@yahoo.co.id,endry.boeriswati@unj.ac.id,Ilzamayuni@unj.ac.id
}

\begin{abstract}
Abstrak
Salah satu alasan bahasa Rejang menjadi bahasa daerah yang diajarkan di sekolah-sekolah Provinsi Bengkulu adalah bahasa ibu tersebut tidak lagi secara aktif menjadi bahasa komunikasi dalam keluarga. Percampuran perkawinan dari suku yang berbeda menambah alasan orangtua tidak menggunakan bahasa Rejang di rumah. Padahal bahasa Rejang menjadi salah satu bahasa kolokial di empat kabupaten di Provinsi Bengkulu. Tentu saja hal ini berdampak pada keberlangsungan bahasa Rejang dalam masyarakat. Pentingya keberlangsungan bahasa Rejang ini mengakibatkan lahirnya peraturan daerah tentang pembelajaran bahasa Rejang di sekolah. Namun dalam implementasinya terdapat banyak persoalan, salah satunya berkaitan dengan kurikulum. Saat ini pengajaran bahasa Rejang sebagai muatan lokal di sekolah dasar tidak mempertimbangkan kebutuhan pengajar dan pembelajar. Pemelajar menerima kurikulum dan silabus hasil dari penyusunan dinas Pendidikan semata yang diimplementasikan dalam pengajaran. Tentu saja, kondisi ini menciptakan berbagai persoalan dalam aplikasinya, baik proses maupun hasil..Salah satu fase yang paling penting dalam pengembangan pengajaran adalah mengetahui kebutuhan pemelajar dalam proses pendidikan. Hasil dari analisis kebutuhan ini akan menentukan model pengembangan pengajaran yang tepat melalui pengembangan kurikulum, silabus dan bahan ajar. Artikel ini bertujuan untuk memaparkan analisis kebutuhan guru dan siswa terhadap pengajaran bahasa Rejang sebagai muatan lokal di sekolah dasar. Penelitian menggunakan metode campuran (mixed method) dengan teknik pengumpulan data berupa wawancara terbuka, observasi dan kuesioner. Subyek penelitian adalah guru di tiga sekolah dan siswa kelas IV di empat sekolah di Kabupaten Rejang Lebong. Data dianalisis menggunakan analisis data kualitatif yaitu reduksi data, penyajian data dan kesimpulan serta analisis data kuantitatif berupa persentase. Temuan penelitian menghasilkan lima hal untuk kebutuhan guru, yaitu masalah yang dihadapi guru, identifikasi prioritas, identifikasi kemampuan, identifikasi sikap dan solusi. Sementara analisis kebutuhan siswa mencakup 5 hal, yaitu: siapa pembelajar bahasa Rejang, tingkat kemahiran, minat siswa, sikap siswa, dan tujuan serta harapan.
\end{abstract}

Kata-kata kunci: analisis kebutuhan, guru, siswa, bahasa Rejang

\section{PENDAHULUAN}

Bahasa Rejang adalah bahasa kolokial dalam masyarakat suku Rejang yang terletak di Provinsi Bengkulu dengan penuturnya tersebar dalam empat kabupaten, yaitu Kabupaten Rejang Lebong, Kabupaten Lebong, Kabupaten Kepahiang dan Kabupatem Bengkulu Utara.McGinn menyebut ada lima dialek, yaitu dialek Musi, dialek Pesisir, dialek Lebong, dialek Rawas dan dialek Keban Agung (McGinn, 2007). Walaupun demikian suku 
Rejang dengan berbagai dialeknya memiliki keterbukaan terhadap bahasa lain yang hidup dalam masyarakat. Hal ini ditunjukkan dalam penelitian yang memaparkan hubungan antar etnis pendatang (Sunda) dengan etnis Rejang (Pribumi) yang dapat berkomunikasi dalam dua bahasa, yaitu bahasa Sunda dan bahasa Rejang (Heryadi \& Silvana, 2013). Empat kabupaten ini dalam pembelajaran bahasa Rejang sebagai muatan lokal telah diajarkan di sekolah selama 10 tahun terakhir ini. Seperti yang disampaikan oleh Muktadir pembelajaran muatan lokal bahasa Rejang terbagi dalam 4 kabupaten dan 6 kabupaten menjadikan bahasa Inggris, Nyanyi daerah, pertanian dan anyaman sebagai muatan lokalnya di Provinsi Bengkulu. (Muktadir \& Agustrianto, 2014).

Tabel 1.1 Pembelajaran Mulok di Provinsi Bengkulu

\begin{tabular}{|c|c|c|}
\hline NO & KABUPATEN & MULOK \\
\hline \multirow[t]{2}{*}{1} & Kota Bengkulu & 1. Bahasa Inggris \\
\hline & & 2. Nyanyi Daerah \\
\hline \multirow[t]{2}{*}{2} & Lebong & 1. Bahasa Inggris \\
\hline & & 2. Bahasa Rejang (Ka Ga Nga) \\
\hline \multirow[t]{2}{*}{3} & Rejang Lebong & 1. Bahasa Rejang (Ka Ga Nga) \\
\hline & & 2. Nyanyi Daerah \\
\hline \multirow[t]{2}{*}{4} & Kepahiang & 1. Bahasa Inggris \\
\hline & & 2. Bahasa Rejang (Ka Ga Nga) \\
\hline \multirow[t]{2}{*}{5} & Benteng & 1. Bahasa Inggris \\
\hline & & 2. Pertanian \\
\hline \multirow[t]{2}{*}{6} & Bengkulu Utara & 1. Bahasa Rejang (Ka Ga Nga) \\
\hline & & 2. Nyanyi Daerah \\
\hline \multirow[t]{3}{*}{7} & Muko Muko & 1. Bahasa Inggris \\
\hline & & 2. Pertanian \\
\hline & & 3. Anyaman \\
\hline \multirow[t]{2}{*}{8} & Seluma & 1. Bahasa Inggris \\
\hline & & 2. Anyaman \\
\hline \multirow[t]{2}{*}{9} & Bengkulu Selatan & 1. Bahasa Inggris \\
\hline & & 2. Anyaman \\
\hline \multirow[t]{2}{*}{10} & Kaur & 1. Bahasa Inggris \\
\hline & & 2. Nyanyi Daerah \\
\hline
\end{tabular}

Dari hasil observasi dan wawancara ke tiga sekolah dasar di Kabupaten Rejang Lebong, yaitu SD Negeri 3 Rejang Lebong, SD Negeri 134 Rejang Lebong dan SD Muh,5 Rejang Lebong pada tanggal 28 Desember 2018, 4 Januari 2019 dan 6 Februari 2019 diketahui kurikulum pembelajaran bahasa Rejang (Ka Ga Nga) masih berdasarkan kurikulum yang disusun oleh Dinas Pendidikan dan Kebudayaan Kabupaten Rejang Lebong. Implementasi kurikulum ini dalam kenyataannya mengalami persoalan yang berkaitan dengan: Pertama, kurikulum yang tidak bersinergi dengan silabus dan bahan ajar. Hal ini diungkapkan dalam wawancara mendalam kepada guru muatan lokal bahasa Rejang yang menyebutkan: "Kalau untuk kurikulum, belum / tidak sesuai. Misal, di kurikulum itu menjelaskan tentang menceritakan tentang kejadian sehari-hari. Sedangkan di buku ini tidak ada. Jadi, kita membuat sendiri." (EY) 
Kedua, bahan ajar yang sulit dipahami siswa. Bahan ajar yang ada tidak memfasilitasi kebutuhan siswa yang berbeda-beda. Siswa dengan latar budaya Rejang dan non Rejang mengalami kesulitan yang berbeda dalam memahami bahan ajar. Seperti yang disampaikan oleh responden berikut: "Siswa Kurang bisa memahami materi ini" (EY) "Ada beberapa anak mudah memahami karena mereka berasal dari suku Rejang, tapi sebagian anak sulit memahami karena beda budaya itu tadi." (SY)

Poin penting dari persoalan di atas adanya penyusunan kurikulum dan bahan ajar yang tidak disesuaikan dengan kebutuhan pengguna. Salah satu fase yang paling penting dalam pengembangan kurikulum adalah mengetahui kebutuhan pembelajar dalam proses pendidikan. Prosedur yang digunakan untuk mengumpulkan informasi mengenai kebutuhan pembelajaran disebut dengan analisis kebutuhan (C.Richards, 2002) Analisis kebutuhan ini hadir dalam rancangan program pendidikan sejak tahun 1960 sebagai bagian dari sistem dan pendekatan dalam pengembangan kurikulum dan menjadi filosofi dari akuntabilitas pendidikan (Stuff Lebeam, Mc Cormick, Brinker hoff, dan Welson (1985) dalam (C.Richards, 2002).

Pendekatan dalam analisis kebutuhan ini mempertimbangkan hal berikut: (1) tujuan dari analisis kebutuhan, (2) asal kebutuhan, (3) untuk siapa analisis kebutuhan, (4) siapa target populasinya, (5) siapa yang mengumpulkan informasi, (6) prosedur yang digunakan, (7) bagaimana informasi yang telah digunakan. Analisis kebutuhan menjadi alat untuk menjaring apa yang menjadi masalah bagi pembelajar, apa yang penting oleh pembelajar dan apa yang dibutuhkan oleh pembelajar (Nation \& Maclister, 2010).

Penelitian yang berkaitan dengan analisis kebutuhan baik untuk pengembangan bahasa maupun pengembangan bahan ajar telah banyak dilakukan. Seperti penelitian yang berkaitan dengan Analisis Kebutuhan Bahan Ajar Bahasa Arab Bagi Tenaga Kerja Indonesia Di Timur Tengah. (Nuruddin, 2016), penelitian Analisis Kebutuhan Dalam Redesain Silabus (RPS) Mata Kuliah Bahasa Indonesia Di Perguruan Tinggi (Helaluddin, 2018), dan penelitian Analisis Kebutuhan Bahasa Inggris Jurusan Tata Boga-PKK UNP Padang (Hafizh \& Ratmanida, 2008). Ketiga penelitian analisis kebutuhan ini menggunakan pendekatan yang berbeda-beda, ada yang menggunakan (Borg \& Gall, 2003) dan Hutchinson dalam (Nation \& Maclister, 2010), namun ada juga yang tidak jelas pendekatan analisis kebutuhan yang digunakan.

Penelitian dalam artikel ini menggunakan indikator yang dikembangkan oleh Rossett (Brown, 1995) untuk menjaring kebutuhan guru, sementara untuk siswa menggunakan indikator yang dikembangkan oleh (Graves, 2000). Produk penelitian yang menggunakan analisis kebutuhan memiliki tingkat kevalidan yang tinggi mengingat, produk tersebut 
dikembangkan melalui penelitian pendahuluan yang mendalam melalui observasi, wawancara mendalam, survey dan analisis dokumen/literatur yang cermat.

Berdasarkan pemikiran logis tersebut, pengajaran bahasa Rejang sebagai muatan lokal menjadi sangat penting untuk diteliti analisis kebutuhannya, sehingga diperoleh produk bisa berupa kurikulum, silabus, atau bahan ajar yang nantinya diaplikasikan dalam pengajaran bahasa Rejang sebagai muatan lokal di sekolah dasar.

\section{METODE PENELITIAN}

Artikel ini menggunakan penelitian campuran dengan metode penelitian yang digunakan metode kualitatif dan kuantitatif. Metode kualitatif dilakukan untuk menjaring kebutuhan guru dengan teknik pengumpulan data berupa wawancara mendalam dan observasi, sementara metode kuantitatif digunakan dalam menjaring kebutuhan siswa dengan teknik pengumpulan data berupa kuesioner. Alat pengumpulan data menggunakan pedoman wawancara dengan indikator yang dikembangkan oleh Rossett dalam (Nation \& Maclister, 2010), angket analisis kebutuhan siswa menggunakan indikator yang dikembangkan oleh (Graves, 2000) dan observasi dengan indikator yang dikembangkan oleh (Dick, Carey, \& Carey, 2005). Analisis data dilakukan secara kualitatif dan kuantitatif. Analisis data kuantitatif dilakukan untuk menganalisis jawaban kuisioner analisis kebutuhan siswa. Langkahnya berupa 1) pengkodean untuk pertanyaan tertutup, 2) mempresentasekan hasil jawaban, 3) menyajikan dalam bentuk tabel (Nazir, 2013). Langkah-langkah analisis kualitatif yaitu: 1) reduksi data yaitu memilih dan memusatkan perhatian pada informasi-informasi atau mentransformasi data kasar yang diperoleh dari pengumpulan data. 2) Penyajian data adalah menyajikan kumpulan informasi hasil reduksi data yang mungkin dapat menjadi jalan untuk penarikan kesimpulan.3) Penarikan kesimpulan dan verifikasi yaitu kegiatan menyimpulkan dan memverifikasi informasi secara terus menerus sampai menjadi rinci dan kokoh. (Miles \& Huberman, 1992).

\section{PEMBAHASAN}

\section{Analisis Kebutuhan Guru}

Kebutuhan guru berkenaan dengan masalah yang dihadapi guru, identifikasi prioritas, identifikasi kemampuan, identifikasi sikap dan solusi. Pertama, masalah yang dihadapi guru mengarahkan pada kebutuhan apa yang paling penting diinginkan guru untuk diatasi. Hasil wawancara mendalam diperoleh temuan kebutuhan guru berkenaan dengan tabel $1.2 \mathrm{di}$ bawah ini: 
Tabel 1.2 Masalah yang Dihadapi Guru

\begin{tabular}{lll}
\hline \multicolumn{1}{c}{ Komponen } & \multicolumn{1}{c}{ Komentar } & \multicolumn{1}{c}{ Keterangan } \\
\hline $\begin{array}{l}\text { Kurikulum, silabus, bahan ajar yang } \\
\text { relevan }\end{array}$ & $\begin{array}{l}\text { Kita mengikuti guru yang } \\
\text { sebelumnya. Kita ikuti buku guru } \\
\text { yang lama }\end{array}$ & $\begin{array}{l}\text { Hanya dari buku, buku paket atau } \\
\text { cetaknya }\end{array}$ \\
Sumber belajar dan media & $\begin{array}{l}\text { biar menarik belajarnya ditambahkan } \\
\text { sedikit-sedikit pakai bahasa Inggris. }\end{array}$ & Perlu diperbaiki \\
Strategi Pembelajaran & Tidak ada Cuma buku cetak itu saja. & Perlu diperbaiki \\
\hline $\begin{array}{l}\text { Sarana dan prasarana yang } \\
\text { mendukung }\end{array}$ & &
\end{tabular}

Kurikulum, silabus, dan bahan ajar dalam pembelajaran bahasa Rejang di Kabupaten Rejang Lebong menjadi persoalan yang mendasar mengingat selama ini pembelajaran muatan lokal dianggap hanya sebagai kegiatan ekstrakurikuler. Hal ini juga berimbas pada sumber belajar dan media yang tersedia. Lemahnya strategi pembelajaran yang dimiliki guru memberikan konsekuensi bagi kurangnya minat siswa terhadap muatan lokal bahasa Rejang ini.

Kedua, kebutuhan guru berkaitan dengan identifikasi prioritas yang menginvestigasi tema, penggunaan struktur bahasa, isi dalam keterampilan yang dianggap penting untuk dipelajari siswa. Dari wawancara mendalam terhadap responden guru diperoleh data kebutuhan guru adalah:

Tabel 1.3 Identifikasi Prioritas Guru

\begin{tabular}{lll}
\hline \multicolumn{1}{c}{ Komponen } & \multicolumn{1}{c}{ Komentar } & \multicolumn{1}{c}{ Keterangan } \\
\hline $\begin{array}{l}\text { Tema/topik yang relevan dengan } \\
\text { kebutuhan siswa }\end{array}$ & $\begin{array}{l}\text { Menurut saya tidak sesuai. } \\
\text { Sebenarnya yang sesuai itu kalau } \\
\text { mengikuti silabus, SK KD, buku, } \\
\text { sarana, media, Tapi karena ini } \\
\text { pelajaran yang hanya pelengkap, kita } \\
\text { secara natural saja belajarnya }\end{array}$ & \\
& $\begin{array}{l}\text { Pembelajaran dengan struktur bahasa } \\
\text { Indonesia }\end{array}$ & Perlu diperbaiki \\
$\begin{array}{l}\text { Penggunaan struktur yang mudah } \\
\text { dipahami }\end{array}$ & $\begin{array}{l}\text { Selama ini tidak berdasarkan materi } \\
\text { Kegiatan pembelajaran berdasarkan } \\
\text { materi }\end{array}$ & Perlu diperbaiki \\
$\begin{array}{l}\text { Kegiatan pembelajaran berdasarkan } \\
\text { alokasi waktu }\end{array}$ & $\begin{array}{l}\text { Alokasi waktu tidak sesuai. Kadang } \\
\text { anak waktunya habis, anak-anak } \\
\text { kerjakan di rumah }\end{array}$ & Perlu diperbaiki \\
& &
\end{tabular}

Ketiga, kebutuhan guru berkaitan dengan mengidentifikasi kemampuan bahasa Rejang yang dimiliki dan berkenaan dengan harapan penggunaan dari keterampilan bahasa Rejang. Jawaban responden guru terhadap indikator ini mulai dari asal responden sebagai pengguna bahasa Rejang sampai dengan kemampuan keterampilan berbahasa yaitu mendengarkan, berbicara, membaca dan menulis menunjukkan memiliki kemampuan berbahasa Rejang yang baik. 
Tabel.1.4 Identifikasi kemampuan Guru

\begin{tabular}{|c|c|c|}
\hline Pertanyaan & Jawaban & Keterangan \\
\hline $\begin{array}{l}\text { Apakah Bpk/Ibu berasal dari suku } \\
\text { Rejang? }\end{array}$ & $\mathrm{Ya}$ & Kemampuan baik \\
\hline $\begin{array}{l}\text { Apakah Bpk/Ibu menggunakan } \\
\text { bahasa Rejang dalam komunikasi } \\
\text { sehari-hari? }\end{array}$ & Ya & Kemampuan baik \\
\hline $\begin{array}{l}\text { Apakah Bpk/Ibu menguasai bahasa } \\
\text { Rejang dari keluarga sebagai bahasa } \\
\text { ibu di rumah? }\end{array}$ & Ya & Kemampuan baik \\
\hline
\end{tabular}

Keempat, kebutuhan guru berkaitan dengan identifikasi sikap guru terhadap bahasa Rejang. Sikap responden terhadap pengajaran bahasa Rejang tergambar dalam jawabanjawaban yang menyatakan senang berbahasa Rejang, sering menggunakan bahasa Rejang, menggunakan bahasa Rejang kepada siapapun, senang mengajarkan bahasa Rejang di kelas, senang mengajar bahasa Rejang kepada siapapun, senang mendengar, membaca dan berbicara bahasa Rejang, namun tidak untuk menulis. Sikap responden menggambarkan posisinya ssebagai pengajar bahasa Rejang yang memiliki harapan yang positif terhadap bahasa Rejang. Artinya dengan kemampuan dan sikap yang baik terhadap bahasa Rejang pengembangan pembelajaran dapat ditingkatkan secara maksimal.

Kelima, identifikasi solusi terhadap masalah belajar dan evaluasi hasil pembelajaran. Kebutuhan guru terhadap pembelajaran bahasa Rejang mementukan tindakan apa yang akan dilakukan menyangkut persoalan-persoalan yang menjadi kendala. Jawaban responden terhadap pertanyaan tersebut mengarah pada upaya perbaikan pada aspek media, strategi pembelajaran, metode, pendekatan dan evaluasi yang efektif.

Hasil Paparan di atas menyimpulkan kebutuhan guru akan berkisar pada hal-hal berikut, yaitu:

a. Kebutuhan guru terhadap kurikulum, silabus dan bahan ajar yang bersinergi, sehingga antar perangkat pembelajaran saling mendukung.

b. Kebutuhan guru terhadap sumber belajar dan media yang relevan, mengingat pembelajaran akan menark minat sisiwa apabila dibantu oleh alat pembelajaran yang merangsang minat siswa.

c. Kebutuhan guru akan strategi pembelajaran yang memudahkan proses pemahaman siswa dan membentuk hasil yang maksimal.

d. Kebutuhan guru akan sarana dan prasarana yang mendukung baik berasal dari sekolah ataupun dari dinas yang terkait.

e. Kebutuhan guru akan tema/topik yang relevan dengan kebutuhan siswa, dengan pertimbangan bahwa belajar bahasa Rejang akan terintegrasi dengan budayanya. Untuk itu tema/topik hendak tidak jauh dari kehidupan sehari-hari masayarakat suku Rejang. 
f. Kebutuhan guru akan struktur bahasa Rejang yang mudah dipahami siswa, karena mengajarkan bahasa akan berkaitan dengan ilmu bahasa, salah satunya tentang struktur bahasa.

g. Kebutuhan guru akan pembelajaran bahasa Rejang berbasis materi.

h. Kebutuhan guru akan pembelajaran bahasa Rejang berbasis alokasi waktu.

\section{Analisis Kebutuhan Siswa}

Analisis kebutuhan siswa dilakukan pada siswa di empat sekolah dengan jumlah responden sebanyak 229 siswa. Responden dipilih hanya pada kelas IV dengan pertimbangan pada usia tersebut, siswa telah mampu membaca, walau dalam kenyataannya bertemu juga dengan beberapa siswa yang belum mampu membaca. Penjaringan kebutuhan siswa menggunakan indikator Graves (2000) yang berjumlah 10 indikator. Hasil kuesioner menampilkan kebutuhan siswa mulai dari hal di bawah ini:

a. Pembelajaran bahasa Rejang ditujukan pada siswa yang telah mengikuti jenjang pendidikan usia dini, yaitu TK.

Diagram 1.1 Latar Pendidikan

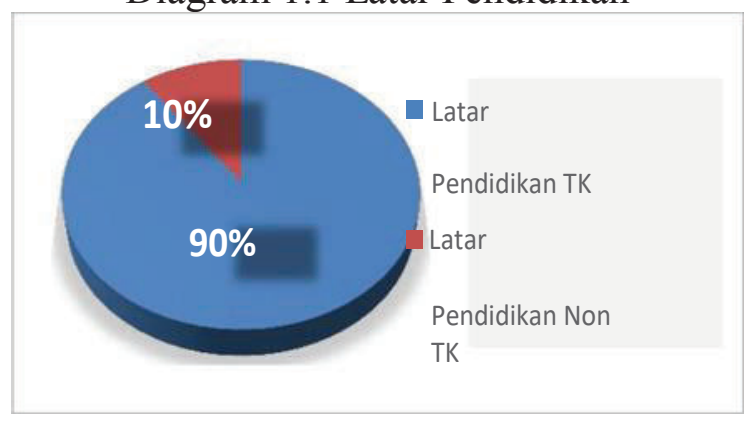

b. Siswa berasal dari suku Rejang 55,80\% dan tidak menggunakan bahasa Rejang dalam kehidupan sehari-hari 80\%. Siswa membutuhkan pembelajaran bahasa Rejang diarahkan pada kegiatan yang merangsang penggunaannya untuk kehidupan seharihari.

c. Siswa membutuhkan penguasaan empat keterampilan berbahasa karena $41 \%$ tingkat kemahiran keterampilan berbahasa siswa rendah.

d. Siswa membutuhkan pembelajaran bahasa Rejang dari aspek tatabahasa, kosakata, pengucapan, dan keterampilan fingsional. 


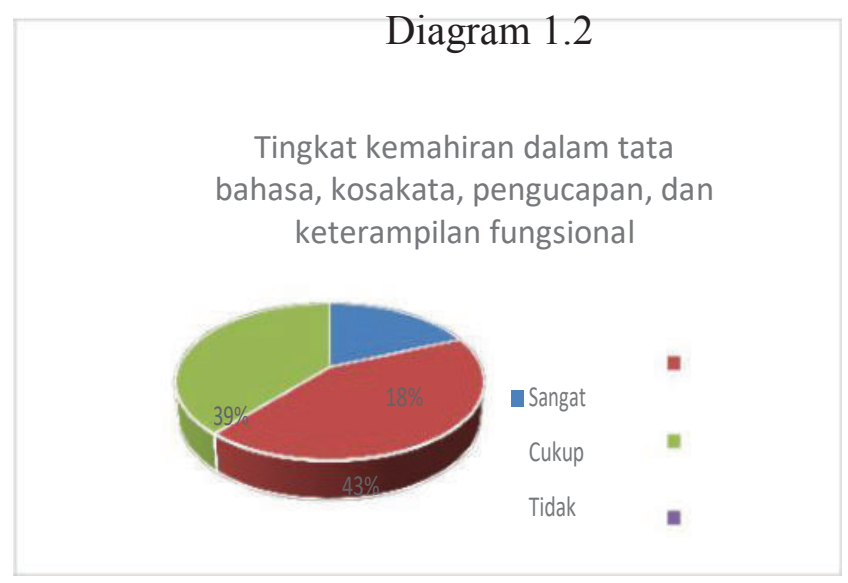

e. Siswa membutuhkan pembelajaran membaca dan menulis dalam bahasa Rejang.

Diagram 1.3

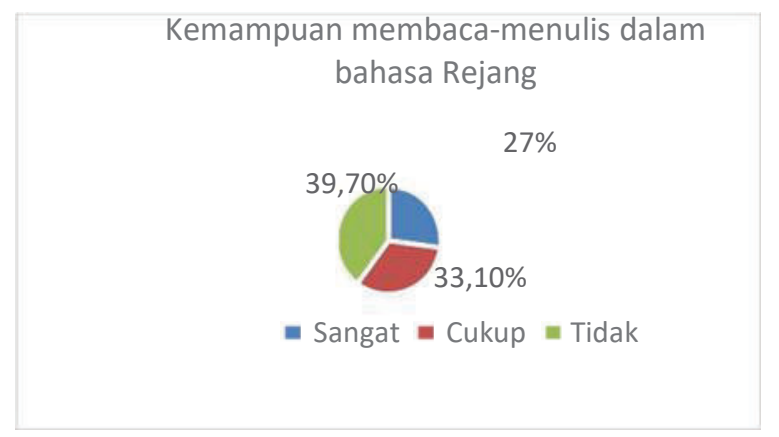

f. Siswa membutuhkan pembelajaran bahasa Rejang dengan menggunakan pendekatan kelompok, karena 44\% siswa merasa baik bekerja dalam kelompok.

g. Pembelajaran bahasa Rejang harus dapat menimbulkan ketertarikan, karena terdapat keseimbangan antara siswa yang sangat suka, cukup suka dan kurang suka terhadap bahasa Rejang.

Diagram 1.4 Suka Belajar Bahasa Rejang

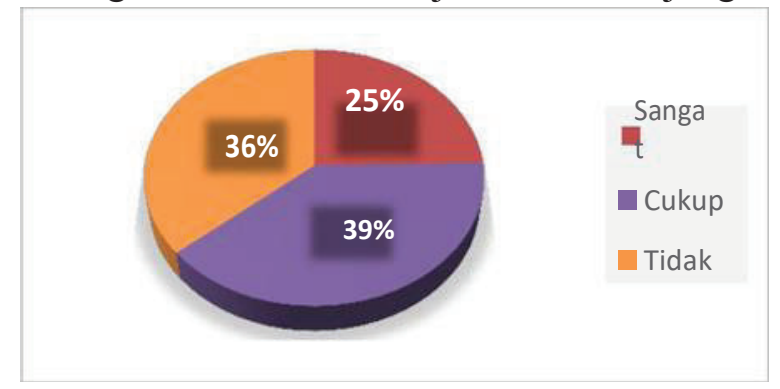

h. Siswa membutuhkan pembelajaran bahasa Rejang yang berbasis pada pendekatan komunikatif, karena 43,3\% siswa ingin berkomunikasi dalam bahasa Rejang.

i. Siswa yang membutuhkan pembelajaran bahasa Rejang berbasis budaya sebesar $60,60 \%$. 
j. Siswa membutuhkan pembelajaran bahasa Rejang untuk situasi yang tidak resmi.

k. Siswa cukup membutuhkan pembelajaran bahasa Rejang untuk tujuan memberi dan mendapatkan informasi $(37,5 \%)$.

1. Siswa cukup membutuhkan pembelajaran bahasa Rejang untuk mendemgarkan cerita nenek $(36,60 \%)$.

m. Siswa membutuhkan pembelajaran bahasa Rejang untuk dapat mendengarkan lagu dalam bahasa Rejang (44,50\%).

n. Siswa cukup membutuhkan materi yang berkaitan dengan panggilan kekerabatan $(41 \%)$.

o. Siswa sangat perlu belajar mendengarkan, berbicara, membaca dan menulis dalam bahasa Rejang.

\section{Rambu-Rambu Pembelajaran Bahasa Rejang}

Hasil analisis kebutuhan guru dan siswa memetakan apa yang menjadi rambu-rambu dalam pembelajaran bahasa Rejang. Rambu-rambu ini akan menjadi indikator bagi pengembangan kurikulum, silabus dan bahan ajar yang dibutuhkan dalam kegiatan pembelajaran. Berdasarkan hal tersebut, rambu-rambu yang dimaksud adalah:

1. Tujuan pembelajaran bahasa Rejang adalah untuk meningkatkan kemampuan berkomunikasi sehari-hari siswa.

2. Pembelajaran bahasa Rejang berbasis budaya Rejang.

3. Pembelajar bahasa Rejang adalah siswa yang berasal dari suku Rejang namun bahasa kolokialnya tidak lagi menggunakan bahasa Rejang.

4. Pembelajaran bahasa Rejang dirancang untuk meningkatkan kemampuan berbahasanya yaitu kemampuan mendengarkan, berbicara, membaca dan menulis.

5. Situasi berbahasa dalam pembelajaran menggunakan situasi bahasa tidak resmi

6. Tema-tema yang menjadi topik dalam pembelajaran merupakan tema yang dekat dengan kehidupan sehari-hari siswa.

7. Fokus materi dalam pembelajaran bahasa Rejang menyangkut pada aspek aspek tatabahasa, kosakata, pengucapan, dan keterampilan fingsional.

8. Pendekatan pembelajaran menggunakan pendekatan komunikatif dengan kerja kelompok sebagai strategi pembelajarannya

9. Kegiatan pembelajaran diarahkan pada peningkatan kemampuan literasi.

10. Pendekatan literasi menggunakan pendekatan literasi berimbang. 


\section{PENUTUP}

Penelitian ini menyimpulkan bahwa pembelajaran bahasa Rejang harus dikembangkan dalam bentuk kurikulum, silabus atau bahan ajar yang bersinergi. Kebutuhan guru dan siswa mengacu pada hal-hal berikut: pertama, tujuan pembelajaran bahasa Rejang yang komunikatif, mengingat pembelajarnya adalah siswa yang berasal dari suku Rejang, namun tidak lagi menggunakan bahasa ibu dalam percakapan sehari-hari. Kedua, peningkatan kemampuan empat keterampilan berbahasa menjadi penting dalam memenuhi kebutuhan tersebut. Ketiga, situasi berbahasa yang dikembangkan dalam situasi tidak resmi. Keempat, menggunakan pendekatan komunikatif dengan kerja kelompok sebagai strateginya. Kelima, kegiatan pembelajaran diarahkan pada peningkatan kemampuan literasi.

\section{DAFTAR PUSTAKA}

Borg, W.R. \& Gall, M.D. (2003). Educational Research: An Introduction (Seven edit). Boston: Allyn and Bacon

Brown, J.D. (1995). The Elements of Language Curriculum: A Systematic Approach to Program Development. Boston: Heinle \& Heinle Publisher

C. Richards, J. (2002). Curriculum Development in Language Teaching. Cambridge: Cambridge University Press

Dick, W., Carey. L. \& Carey, J.O. (2005). The Systematic Design Instruction. Boston: MA Pearson

Graves, K. (2000). Designing Language Course; A Guide for Teachers. Boston: Heinie

Hafizh, M. Al. \& Ratmanida. (2008). Analisis Kebutuhan Bahasa Inggris Jurusan Tata BogaPKK UNP Padang. Lingua Didaktika, 1, 1-14. Retrieved from http:ejournal.unp.ac.id/index.php/linguadidaktika/index

Helaluddin. (2018). Analisis Kebutuhan dalam Redesain Silabus ( RPS ) Mata Kuliah Bahasa Indonesia di Perguruan Tinggi. Jurnal Gramatika, 4(1), 85-104. Retrieved from http://ejournal.stkip-pgri-sumbar.ac.id/index.php/jurnal-gramatika/article/view/2464

Heryadi, H. \& Silvana, H. (2013). Komunikasi antar Budaya dalam Masyarakat Multikultur (Studi tentang Adaptasi Masyarakat Imigran Sunda di Desa Imigrasi Permu Kecamatan Kepahiang Provinsi Bengkulu). Kajian Komunikasi, 1. 95-108.

McGinn, R. (2010). Asal Bahasa Rejang. Rejang Lebong Provinsi Bengkulu: STAIN CURUP

Miles, M.B. \& Huberman, A.M. (1992). Analisis Data Kualitatif (Pertama. Jakarta: Universitas Indonesia Press

Muktadir, A. \& Agustrianto (2014). Pengembangan Model Mata Pelajaran Muatan Lokal Berbasis Kearifan Lokal untuk Meningkatkan Karakter di Sekolah Dasar Provinsi Bengkulu, jurnal Pendidikan Karakter, Volume 3.

Nation, I.S. \& Maclister, J. (2010). Language Curriculum Design. New York: Routledge Taylor $\&$ Francis Group

Nazir, M. (2013). Metode Penelitian. Bogor: Ghalia Indonesia

Nuruddin. (2016). Analisis Kebutuhan Bahan Ajar Bahasa Arab bagi Calon Tenaga Kerja Indonesia (TKI) di Timur Tengah. Bahasa dan Seni, 44, 149-161. https://doi.org/dx.doi.org/10.17977/um015v44i22016p159 